\title{
Article \\ Effect of Seaweed Extract Supplement on Rice Rhizosphere Bacterial Community in Tillering and Heading Stages
}

\author{
Chun-Lin Chen ${ }^{1,2}$, Wan-Lin Song ${ }^{1}$, Lin Sun ${ }^{1}$, Song Qin ${ }^{1} \oplus$, Cheng-Gang Ren ${ }^{1}$, Jian-Chao Yang ${ }^{3}$, Da-Wei Feng ${ }^{1}$, \\ Ning Liu ${ }^{3}$, Jun Yan ${ }^{4}$, Bi-Bo Cui ${ }^{4}$, Zhi-Hai Zhong ${ }^{1}$, Qing-Quan Li ${ }^{1}$, Zhi-Dan Liu ${ }^{2}$ and Zheng-Yi Liu ${ }^{1, *}$ \\ 1 Yantai Institute of Coastal Zone Research, Chinese Academy of Sciences, Yantai 264003, China; \\ sy20193091739@cau.edu.cn (C.-L.C.); wlsong@yic.ac.cn (W.-L.S.); sunlin89757@163.com (L.S.); \\ sqin@yic.ac.cn (S.Q.); cgren@yic.ac.cn (C.-G.R.); dwfeng@yic.ac.cn (D.-W.F.); zhzhong@yic.ac.cn (Z.-H.Z.); \\ zfbsjgb@126.com (Q.-Q.L.) \\ 2 College of Water Resources and Civil Engineering, China Agricultural University, Beijing 100083, China; \\ zdliu@cau.edu.cn \\ 3 Institute of Intelligent Agriculture, Yantai Academy of Agricultural Science and Technology, \\ Yantai 265500, China; yangjianchao_china@aliyun.com (J.-C.Y.); liuning1118@163.com (N.L.) \\ 4 Xinyang Agricultural Experiment Station of Yancheng City, Yancheng 224049, China; yj111708@sina.com (J.Y.); \\ cuibibo1971@163.com (B.-B.C.) \\ * Correspondence: zyliu@yic.ac.cn
}

check for updates

Citation: Chen, C.-L.; Song, W.-L.; Sun, L.; Qin, S.; Ren, C.-G.; Yang, J.-C.; Feng, D.-W.; Liu, N.; Yan, J.; Cui, B.-B.; et al. Effect of Seaweed Extract Supplement on Rice Rhizosphere Bacterial Community in Tillering and Heading Stages. Agronomy 2022, 12, 342. https://doi.org/10.3390/ agronomy12020342

Academic Editors: Othmane Merah, Purushothaman Chirakkuzhyil Abhilash, Magdi T. Abdelhamid, Hailin Zhang and Bachar Zebib

Received: 10 January 2022

Accepted: 26 January 2022

Published: 29 January 2022

Publisher's Note: MDPI stays neutral with regard to jurisdictional claims in published maps and institutional affiliations.

Copyright: (C) 2022 by the authors. Licensee MDPI, Basel, Switzerland. This article is an open access article distributed under the terms and conditions of the Creative Commons Attribution (CC BY) license (https:// creativecommons.org/licenses/by/ $4.0 /)$.
Abstract: Rhizosphere microbiota are conducive to soil nutrient cycling for plant growth. Longterm and excessive application of chemical fertilizer is harmful to agriculture. Seaweed extract is a good organic substitute for rhizosphere ecosystem and plant growth. We supplemented 5\% seaweed extract powder to chemical fertilizer, and then studied its effect on rhizosphere bacteria of japonica rice (Oryza sativa L. subsp. japonica). In a short-term experiment, we compared the changes in rhizosphere bacteria among four treatments, i.e., no fertilizer (T1), chemical fertilizer only (T2), chemical fertilizer with 5\% seaweed extract (T3), and less chemical fertilizer with $5 \%$ o seaweed extract (80\% of that of T3) (T4). Results show that seaweed extract supplement could affect the bacterial community in tillering and heading stages; the $\alpha$-diversity of rhizosphere bacteria in the heading stage was obviously improved. In addition, seaweed extract supplement improved significantly the content of nitrate nitrogen $(\mathrm{N})$, available phosphorus $(\mathrm{P})$, and available potassium $(\mathrm{K})$ in rhizosphere soil in the tillering stage, and, finally, increased the rice yield and quality mildly. Therefore, the seaweed extract supplement is shown to be a potential strategy to enrich the diversity of rhizosphere bacteria, which enhanced soil nutrient level, increased rice yield and quality, and also saved the use of chemical fertilizer.

Keywords: short-term fertilization; seaweed extract supplement; rhizosphere microbial community; tillering stage; heading stage; japonica rice

\section{Introduction}

The rhizosphere is an important supporting area for complicated interaction among the plant, soil, and microorganism. Rhizosphere microorganisms contribute to the release of organic acids, amino acids, carbohydrates, and secondary metabolism products [1,2]. In addition, it is reportedly responsible for the degradation and transformation of organic matter and concomitant release of nutrient [3], the generation of plant hormone [4], and the improvement of plant mineral nutrition and formation of soil aggregate [5]. After colonization, root-associated microbial communities can promote plant growth and health by enhancing the utilization and availability of nutrient, synthesizing phytohormones, and resisting against pathogens [6,7]. The soil microbiome plays a key role in modulating plant diversity and nutrient retention and recycling [8]. Notably, nutrient inputs to cultivated soils could alter microbial community structure and activities, which could greatly influence 
their environmental fate [9]. Therefore, it is important to study the effect of fertilization on rhizosphere microbes.

Chemical fertilizers are widely used in agriculture [10]. However, long-term and excessive application of chemical fertilizer can reduce microbial diversity, weaken plant-microbe interaction, destabilize soil microbial function, and obstruct nutrient cycling [6,9,11], which consequently causes soil acidification and consolidation [12,13], and consequently deteriorates soil health and impede sustainable soil fertility in the long run [14,15]. Several solutions have been provided for this issue; for example, managing the soil microbiome, maintaining well-balanced soil microbial diversity $[6,16]$, and supplementing organic fertilizer or biostimulants [17-19]. Seaweed extract has been regarded as a potential way for organic and sustainable agriculture. In fact, seaweed extracts were widely used in agriculture, aquaculture, food, and medical industry due to their availability and special physicochemical properties [15,18-20]. In addition, in agricultural application, biodegradable seaweed extract, as a biostimulant, can be easily accessible and have no side effects [15], which meets the requirements for sustainable agriculture and crop productivity for soil amendment with better growth-promoting effects, stronger resistance capacity, and more microbial stimulants [20-22]. In addition, seaweed extract was also recognized as the best modern sustainable biological plant growth promoter, containing rich bioactive compounds, such as milbemycin oxime, rhodopin, nonadecane, phytol, ascorbic acid, phenolics, flavonoids, etc. [15,23]. Wang et al. (2018) revealed that a short-term application of Sargassum horneri extract could strongly influence the bacterial community, as well as improve tomato yield and vitamin C and lycopene contents [24]. Durvillaea potatorum and Ascophyllum nodosum extract increased the total bacterial count, the bacterial community associated with soil health, and available soil nitrogen content [13]. Mixture of Ulva lactuca, Jania rubens, and Pterocladia capillacea extract can increase cucumber yield by improving its chemical and physical traits related to immunity, productivity, and stress defense [15]; it can also enhance the morpho-agronomic and bioactive properties of hot pepper, including improving content of chlorophyll, ascorbic, phenolic compounds, flavonoids, and enhancing the level of total antioxidant activity, and, finally, increasing Capsicum annuum yield [23]. Mukherjee et al. summarized that seaweed extract had antimicrobial activity against Pseudomonas syringae and Xanthomonas Oryzae pv. oryzae, responsible for rice leaf spot, and some soil-borne pathogens, such as Macrophomina phaseolina [25]. Seaweed extract also increased the number of bacteria in flowering and full maturity stages [26]. Furthermore, studies also reported that seaweed extract spray on leaf significantly improved the leaf area and essential oil yield of rosemary (Rosmarinus officinalis L.) as compared with organic or inorganic fertilizer [27]. It was confirmed that Ascophyllum nodosum extract greatly promoted the growth of maize seedlings [28]. Fertilizing wine grape with Durvillaea potatorum and Ascophyllum nodosum extracts increased the wine grape production for many years, regardless of the occurrence of climate extremes [29]. However, exclusive use of seaweed extract may not meet the nutrient requirement for crops, as it releases nutrients slowly [30]. Therefore, combined use of chemical fertilizer and seaweed extract is a potential approach in nutrient management.

Rice (Oryza sativa L. subsp. japonica) is an important staple cereal grown worldwide, and its yield is always an important index in rice farming. However, sustainable soil health needs to be considered carefully [31]. To secure future food supply, it is urgent to find better nutrient management practices to maintain soil health for higher crop productivity $[15,23]$. N, P, and K are common and important nutrients in soil for affecting rhizosphere microbiota and, subsequently, the growth and productivity $[4,32,33]$. Besides, tillering and heading are critical stages of rice harvest by increasing tillering numbers and the vegetative process [34]. Therefore, exploring the potential effects of seaweed extract supplement on the rice rhizosphere bacterial community is very meaningful.

Intensive cultivation and fertilization caused soil degradation, which demands for proper use of organic fertilizer. Combining organic fertilizer with inorganic fertilizer was proven beneficial to soil quality and crop growth [35,36]. Using seaweed extract also allowed the use of a lower amount of classical mineral fertilizers [23]. As a type of organic 
material, seaweed extract has been used as an alternative environmentally friendly agent to improve crop growth and restore soil fertility [16], and has been expected to be a potential strategy of sustainable agriculture in the future. Therefore, the feasibility of using combined seaweed extract with chemical fertilizer as an alternative to conventional chemical fertilizer is studied in this attempt.

In this study, we carried out a short-term experiment in a paddy field of japonica rice. The growth performance of the treatments on rhizosphere bacterial community in the tillering stage and heading stage was observed and compared. In addition, 16Sr RNA gene amplicon sequencing of V3 and V4 hypervariable regions was used in the analysis of the bacterial community.

\section{Materials and Methods}

\subsection{Sites and Soil Sampling}

This study was performed in Yancheng Agricultural Experiment Station in Jiangsu Province, China $\left(12^{\circ} 8^{\prime} 86^{\prime \prime} \mathrm{E}, 33^{\circ} 23^{\prime} 16^{\prime \prime} \mathrm{N}\right)$, using the japonica rice variety "Nanjing $9108^{\prime \prime}$. The total experimental area was $400 \mathrm{~m}^{2}$, and was divided into $4 \mathrm{~m} \times 4 \mathrm{~m}$ units at intervals of $1 \mathrm{~m}$ (total of 16 fields) (Figure 1).

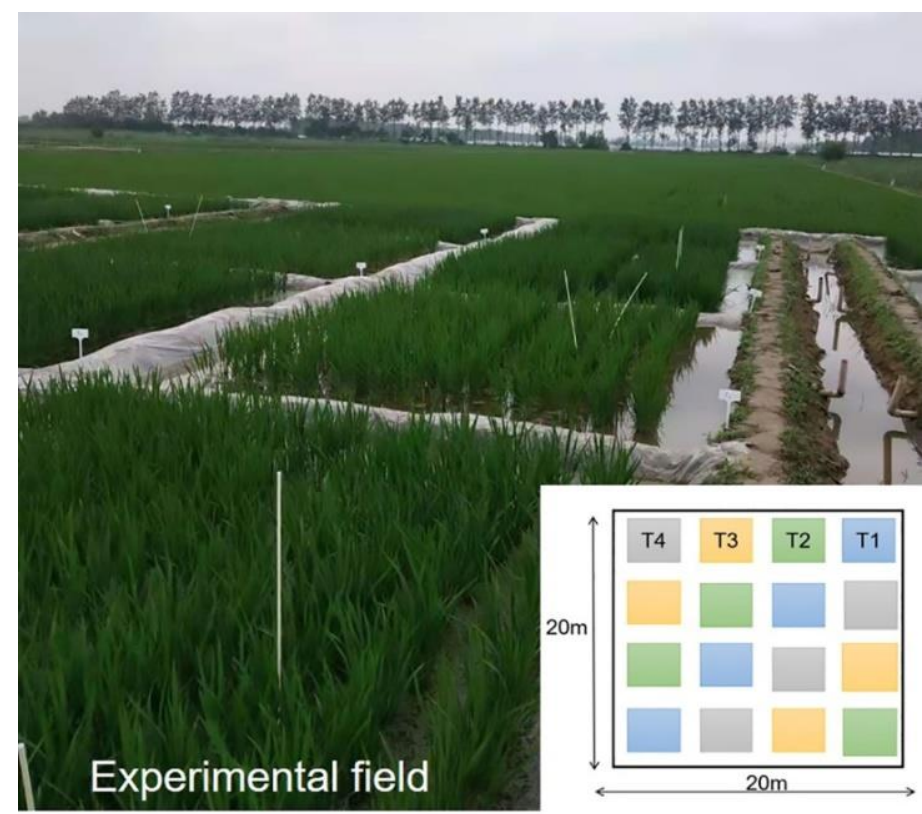

Figure 1. The field view of the experimental design. Units with the same color represent the same treatment.

Soil samples were collected from rice roots of 16 fields, including unfertilized soil samples collected from the experimental field after ploughing (June 18), samples of the tillering stage were collected 3 weeks after the seedlings were transferred into the fields, in the early tillering stage (July 16), and samples of the heading stage were collected 7 weeks after transferring (August 13), in the early heading stage. Three representative individuals of rice were selected from a central position.

Physiochemical properties of soil are important parameters (Table 1). By mixing $5.0 \mathrm{~g}$ soil with $12.5 \mathrm{~mL}$ distilled water, $\mathrm{pH}$ of soil was determined with a $\mathrm{pH}$ electrode. Nitrate nitrogen was determined in dual wavelength ultraviolet spectrophotometry [37]. Available phosphorus content was determined by ammonium fluoride-hydrochloric acid colorimetric method [38]. Available potassium was extracted with ammonium acetate and determined in flame photometry [39]. 
Table 1. Physiochemical properties of paddy field soil before experiment.

\begin{tabular}{ccccc}
\hline \multirow{2}{*}{ Group } & $\mathbf{p H}$ & Nitrate Nitrogen & Phosphorus & Potassium \\
\cline { 3 - 5 } & & & $\mathbf{( m g} / \mathbf{k g})$ & \\
\hline T1 & $8.03 \pm 0.06$ & $19.15 \pm 3.83$ & $31.30 \pm 3.80$ & $195.30 \pm 47.06$ \\
T2 & $7.96 \pm 0.07$ & $21.16 \pm 6.30$ & $25.83 \pm 0.31$ & $173.56 \pm 12.76$ \\
T3 & $8.01 \pm 0.10$ & $18.85 \pm 5.86$ & $33.23 \pm 4.45$ & $187.82 \pm 15.47$ \\
T4 & $8.01 \pm 0.04$ & $16.64 \pm 3.14$ & $30.78 \pm 7.85$ & $202.79 \pm 11.43$ \\
\hline
\end{tabular}

The data in Table 1 represent mean $\pm \mathrm{SD}(\mathrm{n}=3)$, and there are no significant differences between treatments at the level of $p<0.05$.

\subsection{Experimental Groups}

In Table 2, Sargassum horneri extract was prepared by biological fermentation of Bacillus Litoralis [40], under the conditions of seaweed powder: distilled water at 1:10 (w/v), $\mathrm{pH} 7.0$, $30{ }^{\circ} \mathrm{C}$, and $10 \%$ starter culture fermented for $24 \mathrm{~h}$. The fermented liquid contained $2-4 \mathrm{DP}$ (degree of depolymerization) alginate oligosaccharide in a concentration of $1.89 \mathrm{mg} / \mathrm{mL}$, which has been proved effective on tomato root and seedlings [40]. In this study, we spraydried the fermented liquid, then added $5 \% \mathrm{~S}$. horneri extract powder into chemical fertilizer $\left(\mathrm{N}-\mathrm{P}_{2} \mathrm{O}_{5}-\mathrm{K}_{2} \mathrm{O}: 18-20-8\right)$. The base fertilizer was applied on 20 June 2019, and the topdressing was applied on 2, 12, and 25 July 2019. All fertilizations were applied by root application.

Table 2. Treatments and fertilizer application in different groups.

\begin{tabular}{ccc}
\hline Group & Base Fertilizer/g & Total Topdressing/g \\
\hline T1: negative control & 0 & 0 \\
T2: chemical fertilizer & 720 & 1440 \\
( $\left.\mathrm{N}-\mathrm{P}_{2} \mathrm{O}_{5}-\mathrm{K}_{2} \mathrm{O}: 18-20-8\right)$ & 720 (contained 3.6 g S. horneri & 1440 (contained 7.2 g S. horneri \\
T3: chemical fertilizer with & extract powder) & 1152 (contained 5.76 g \\
$5 \%$ S. horneri extract powder & S. horneri extract powder) \\
T4: less chemical fertilizer & 576 (contained 2.88 g S. horneri & \\
with 5\%o S. horneri extract & extract powder) & \\
powder (80\% of that of T3) & & \\
\hline
\end{tabular}

\subsection{Rice Quality}

The mature rice was harvested on 31 October, dried, and then weighed on an electronic balance. The quality of the rice grains was assessed in the Rice Product Quality Supervision and Inspection Center, the Ministry of Agriculture and Rural Affairs (China). Indexes of brown rice rate, chalkiness degree, chalky rice rate, transparency, gelatinization temperature, and milled rice rate were determined based on China's agriculture standard NY/T 83-2017. The head rice rate, adhesive strength, amylose content, grain length, and protein content were gauged against China's applicable national standards GB/T 21719-2008, GB/T 22294-2008, GB/T 15683-2008, GB/T 24535-2009, and GB 5009.5-2016, respectively.

\subsection{S rRNA Gene Amplicon Sequencing}

For DNA extraction and PCR amplification, a DNA extract was obtained as per the manufacturer's specifications of Magnetic Soil and Stool DNA Kit (Beijing Tiangen Biotech Co., Ltd., China), and then a bacterial community profile was generated for each sample via PCR amplification of the $16 \mathrm{~S}$ rRNA gene targeting regions $\mathrm{V} 3$ and $\mathrm{V} 4$ with primers $341 \mathrm{~F}$ $\left(5^{\prime} \rightarrow 3^{\prime}\right.$ : CCTAYGGGRBGCASCAG) and 806R $\left(5^{\prime} \rightarrow 3^{\prime}\right.$ : GGACTACNNGGGTATCTAAT). The PCR products were verified in $2 \%$ agarose gel electrophoresis using recovered kits.

High-throughput sequencing of the V3 and V4 regions of 16S rRNA genes. Total genomic DNA was subject to high-throughput sequencing of the 16S rRNA amplicons on Illumina MiSeq platform in the Novogene Biotechnology Co., Ltd. (Tianjin, China). The 16S rRNA gene data were analyzed using the Novomagic Cloud Platform (https: / / magic.novogene.com/, accessed on 26 January 2022). 
Bacterial communities were analyzed using different bioinformatics tools and pipelines. The Quantitative Insights into Microbial Ecology (QIIME) was used for merging paired-end reads [41,42]. Based on Uparse (v7.0.1001), high-quality sequences were clustered into the same operational taxonomic units (OTUs) with 97\% identity [43]. Species annotation was developed based on the Mothur method and SSUrRNA database of SILVA138 (threshold value of $0.8 \sim 1)[44,45]$.

\subsection{Statistical Analyses}

For alpha diversity and beta diversity, R software (v 2.15.3) was used for bacterial diversity analysis. Differences of $\alpha$-diversity among groups were assessed by the agricolae package with Wilcox test. PCoA analysis was carried out by the stats and ggplot2 packages on the weighted UniFrac distance, and that of non-metric multidimensional scaling (NMDS) was analyzed by the vegan package based on Bray-Curtis dissimilarity matrix.

For function prediction. Tax4Fun prediction was realized by extracting the whole 16SrRNA gene sequence from the KEGG database, and the BLASTN algorithm was used to pick the sequence to SILVA SSU Ref NR database (BLAST bitscore > 1500) for the establishment of the correlation matrix. UProC and PAUDA methods correspond to the SILVA database to realize the functional annotation of the SILVA database.

For chemical analysis. Assessment of soil nutrients and rice yield was realized by oneway analysis of variance (ANOVA) using SPSS software (version 20.0), and the significance was analyzed using the Duncan ${ }^{\mathrm{a}, \mathrm{b}}$ test. Histograms were drawn by Origin software (v 2021b). A probability level of $p<0.05$ was considered significant.

\section{Results}

In this study, 1,240,607 effective tags were obtained from 27 samples (on average of 45,948; range 36,545-62,722 tags per sample), clustered with $97 \%$ identity, and then had chimeric sequences removed to produce 9813 operational taxonomic units (OTUs).

\subsection{Changes in Rice Rhizosphere Soil in theTillering Stage}

The dominant phyla in rhizosphere soil were Actinobacteriota, Proteobacteria, Acidobacteriota, Bacteroidota, Firmicutes, and Chloroflexi, accounting for more than $75 \%$ of total bacteria. The original soil bacterial community was diverse and rich due to frequent cultivation and ploughing in advance (Figure 2a,b). Fertilization has great influence on rice rhizosphere bacterial communities. Compared to that of T2, soils that were treated with seaweed extract supplement (T3) showed increases in relative abundance of Actinobacteria, Firmicutes, and Chloroflexi by $41.42 \%, 21.17 \%, 12.59 \%$, respectively, while there was a decrease in Acidobacteriota by $19.76 \%$. In particular, T1 had higher relative abundance of Actinobacteriota and Bcteroidota than other groups (Figure 2a), while T3 and T4 had significantly enriched Latescibacterota and Chloroflexi, respectively (Figure $2 c)(p<0.05)$. Besides, the rice root enriched mainly bacterial families of Micrococcaceae, Sphingomonadaceae, Hymenobacteraceae, Xanthomonadaceae, Gemmatimonadaceae, and Vicinamibacteraceae. Compared to T2, the relative abundance of Micrococcaceae in T3 and T4 increased, T3 in particular also had Enterobacteriaceae enriched, and, in T3 and T4, that of Oxalobacteraxeae decreased (Figure 2b). Besides, in T2 and T4, the Chao1 index in the tillering stage was significantly improved as compared that in T1 (Figure $2 \mathrm{~d})(p<0.05)$, showing that bacterial community richness increased.

As shown in Figure 3a, there were significant differences in the levels of $N$, $\mathrm{P}$, and $\mathrm{K}$ in rice rhizosphere soils in the tillering stage among four groups $(p<0.05)$. Especially in T4, compared to that in other groups, the level of $\mathrm{N}, \mathrm{P}$, and $\mathrm{K}$ in rhizosphere soil in T4 increased by $27.27 \%$ to $45.61 \%, 20.19 \%$ to $45.61 \%$, and $19.32 \%$ to $47.89 \%$, respectively. Although the levels of N and P of T2 and T3 were mildly higher than that of T1, there was no significant difference in the levels of $\mathrm{N}$ and P among T1, T2, and T3. Moreover, the Spearman analysis showed that Proteobacteria and Acidobacteriota were positively related to N content; Chloroflexi, Cyanobacteria, and especially Verrucomocrobiota were positively 
related to P content; and Acidobacteriota and Cyanobacteria positively related to K content, while Bacteroidota was negatively related to it (Figure 3b).

(a)

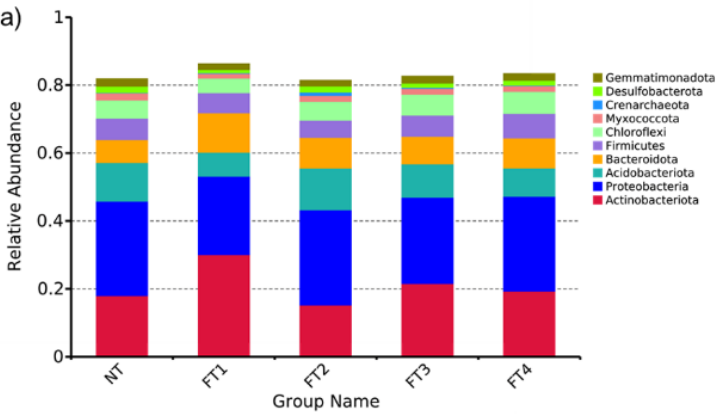

(b)

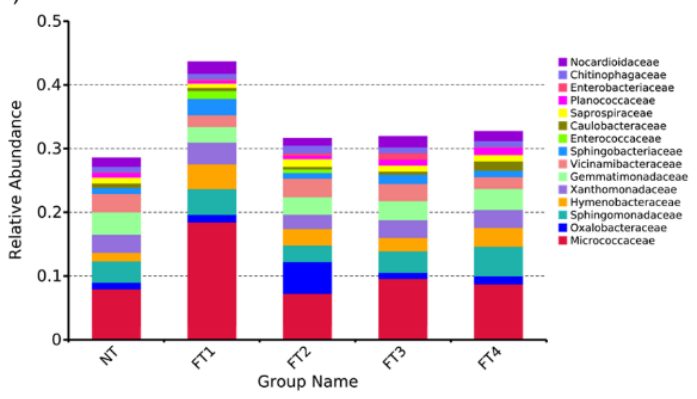

(c)

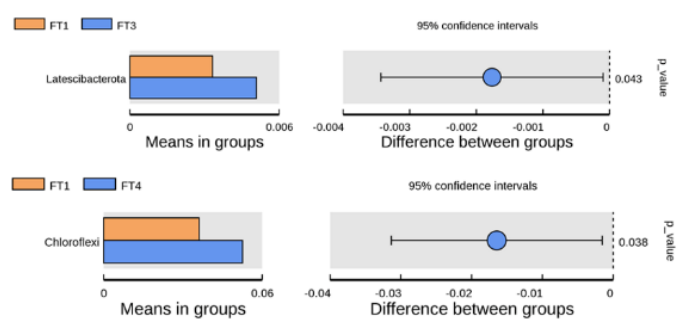

(d)

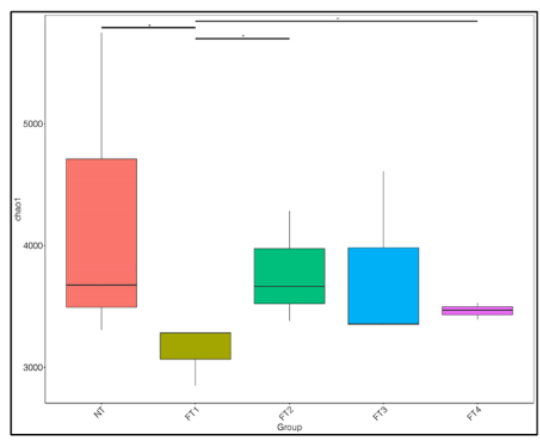

Figure 2. The shift of microbial composition $(\mathbf{a}-\mathbf{c})$ and the $\alpha$-diversity $(\mathbf{d})$ of bacteria in the tillering stage. NT: before fertilization, FT: tillering stage, YT: heading stage. The following NT, FT, YT in the chart below were the same as this reference. (a) Top 10 phyla of rhizosphere bacteria in the heading stage; (b) top 15 families of rhizosphere bacteria in the heading stage; (c) bacterial difference between groups; (d) the Chao1 index.

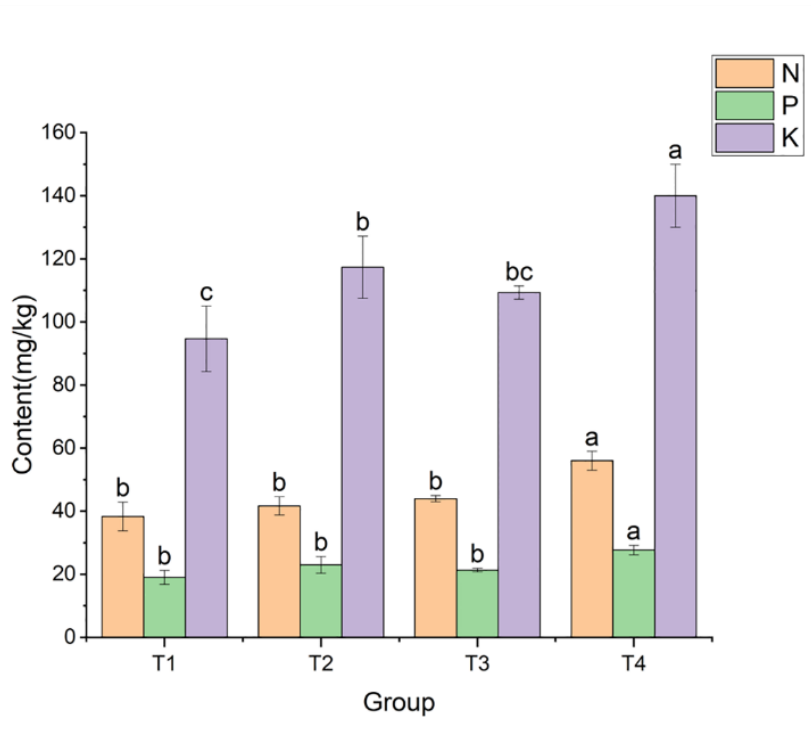

(a)

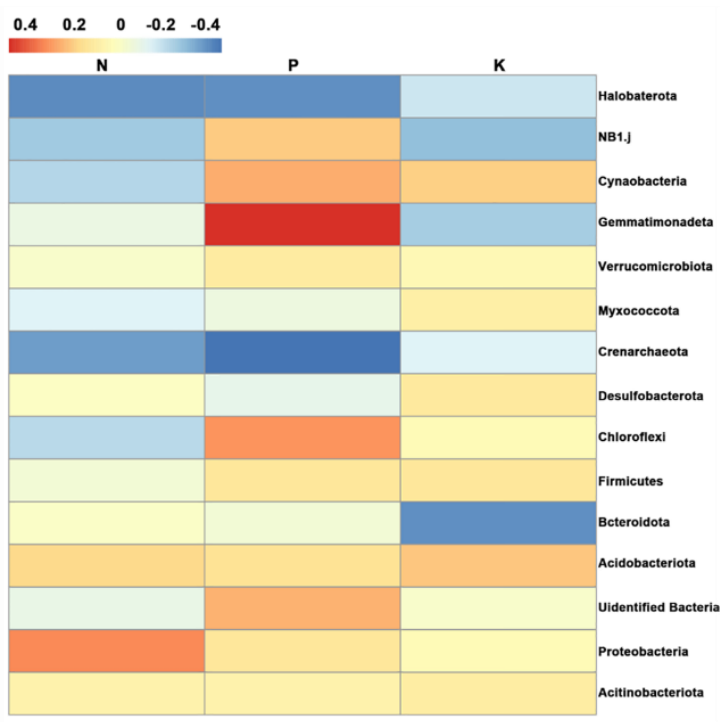

(b)

Figure 3. The shift in soil N, P, and K in different treatments (a) and Spearman analysis (b). The mean values of volumes in the same color that are followed by the same letter showed no significant difference $(n=3)$.

\subsection{Changes in Rice Rhizosphere Soil in the Heading Stage}

In the heading stage, Proteobacteria, Actinobacteriota, Bacteroidota, Firmicutes, Acidobacteriota, and Chloroflexi were dominant phyla in the soil samples, representing approximately 
$80 \%$ of total rhizosphere bacteria. It can be observed that the Proteobacteria and Bacteroidota were more concentrated, while Acidobacteriota decreased from that in the tillering stage (Figure 4a). In the family level, Micrococcaceae, Sphingomonadaceae, Hymenobacteraceae, Xanthomonadaceae, Gemmatimonadaceae, and Vicinamibacteraceae were dominant families. T3 and T4 had lower relative abundance of Hymenobacteraceae, Xanthomonadaceae, and Enterococcaceae than that of T2 (Figure 4b). Moreover, in T3 and T4 groups, the Chao1 index and Shannon index increased compared to that of T2 (Figure 4c,d). Notably, OTUs in the experimental fields were enriched, showing obvious overlaps in differentially abundant OTUs among the four groups where 2758 OTUs were in common. Among groups, 240 OTUs are common in T2 and T3, and 312 OTUs were common in T3 and T4. In T1, T2, T3, and T4 groups, 482, 564, 670, and 796 unique OTUs were enriched, respectively (Figure 4e). Therefore, fertilization increased the number of unique OTUs in soil samples. Particularly, seaweed-extract-supplement fertilizer had great improvement on the rice development.

(a)

(c)

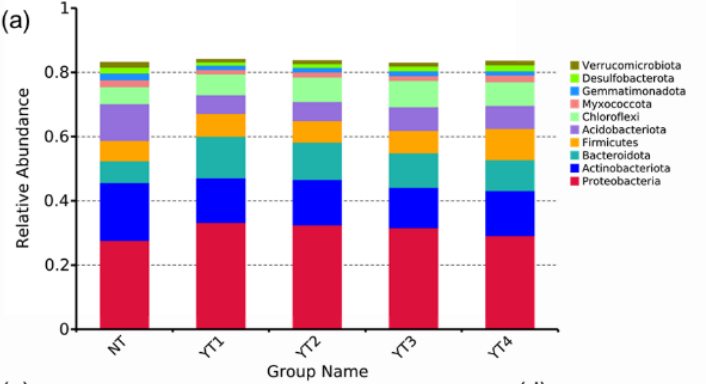

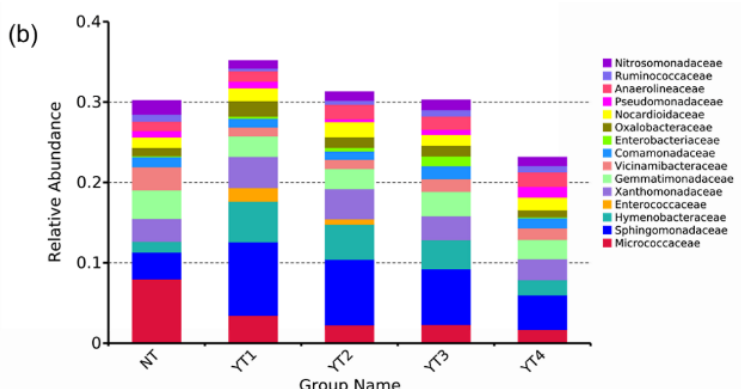

(e)
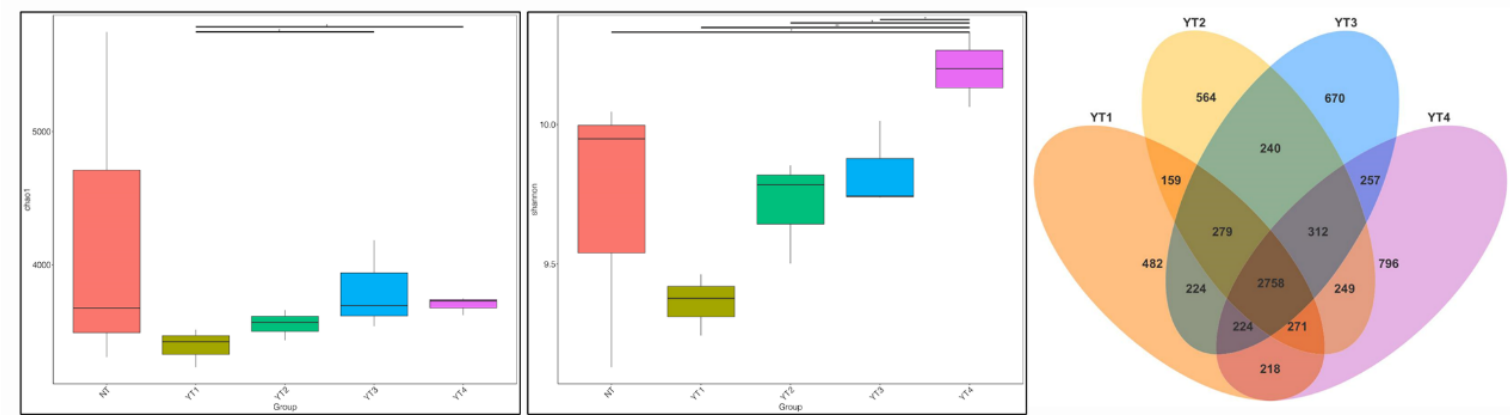

Figure 4. The shift in microbial composition $(\mathbf{a}, \mathbf{b})$ and $\alpha$-diversity $(\mathbf{c}, \mathbf{d})$ of bacteria in the heading stage. (a) Top 10 phyla of rhizosphere bacteria; (b) Top 15 families of rhizosphere bacteria; (c) Chao1 index; (d) Shannon index; (e) bacterial OTUs.

\subsection{Bacterial Changes in $\beta$-Diversity and Composition Induced Different Functional Responses}

We found that the composition of the rhizosphere microbiota differed in four groups. Principal co-ordinate analysis (PCoA) revealed that the root microbiota formed two different clusters, which separated along the second co-ordinate axis. PCoA 1 and 2 explained 29.98\% and $19.24 \%$ of the total variance, respectively (Figure 5a). Nonmetric multidimensional scaling (NMDS) analysis also gave information about the variation degree among samples (Figure $5 \mathrm{~b}$ ); the soil samples treated by seaweed-extract fertilizer clustered closer. It can be further revealed in Figure $5 \mathrm{c}$ that the difference in bacterial diversity was more similar in seaweed-extract-fertilizer treatment. The relative abundance of the main phyla indicated that the bacterial community changed a lot among the four groups in the heading stage (Figure 5d). These results indicated that the source of variation in the rice root microbiota was proximity to the fertilization treatment and growth stage. 
(a)

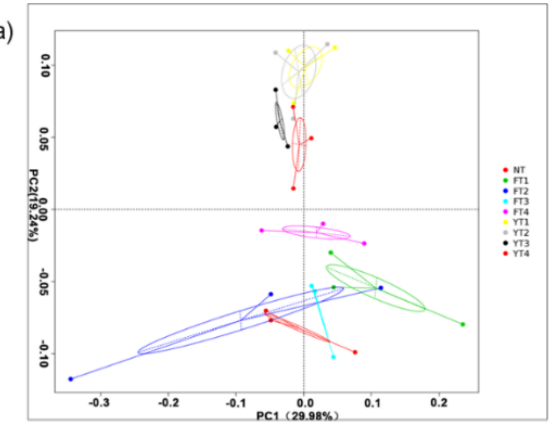

(b)

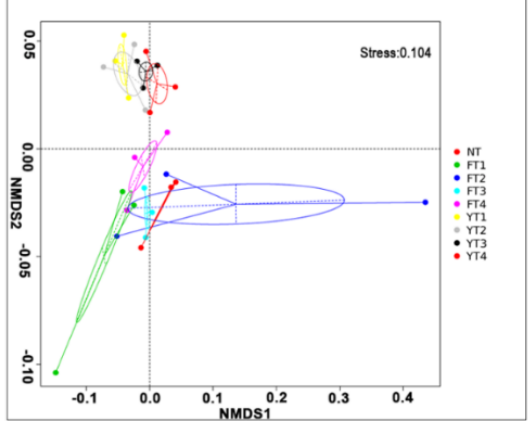

(c)

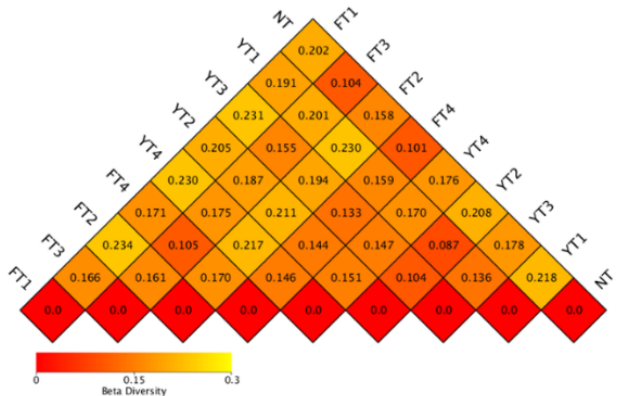

(d)

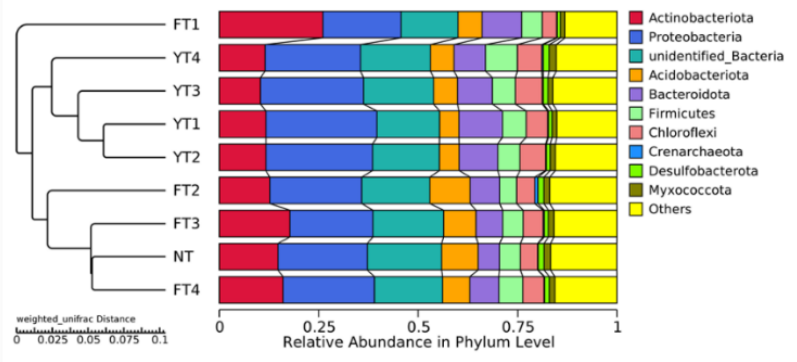

Figure 5. The shift in bacterial $\beta$-diversity $(\mathbf{a}-\mathbf{c})$ and composition $(\mathbf{d})$ of bacteria in different treatments. (a) Principal co-ordinates analysis (PCoA) of weighted UniFrac distance. Variance explained by each axis is shown in parentheses. (b) Nonmetric multidimensional scaling (NMDS) results of Bray-Curtis distance. (c) Heatmap of weighted UniFrac distance. The number represents coefficient of difference between groups. (d) Relative abundance of bacteria at phylum level.

Different microbiota contribute to divergent ecological functions for adaption to environmental change. Tax4Fun analysis was conducted to compare differences among the four groups (Figure 6a). In this study, KEGG orthologs are related to membrane transport, transition, replication and repair, carbohydrate metabolism, and amino acid metabolism, and they were enriched in the rhizosphere; however, KEGG orthologs were in low abundance during cellular processes, and they were the lowest in cell growth and death in signaling molecules and interaction.

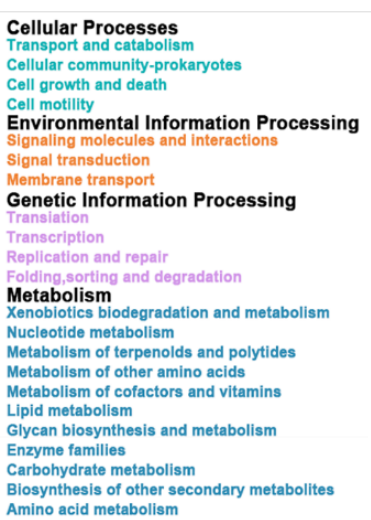
Amino acid metabolism

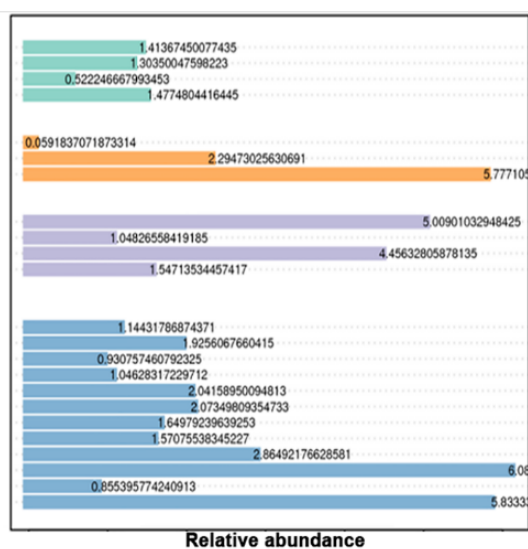

(a)

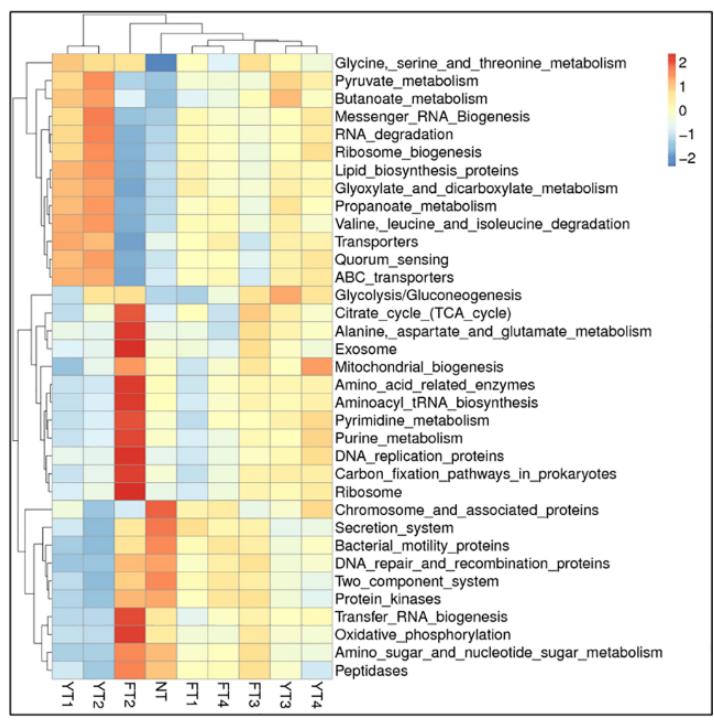

(b)

Figure 6. The predictive functional metagenome composition in rhizosphere soil. (a) KEGG pathway at level 1; (b) KEGG pathway at level 3. 
Level-3 KO groups are functionally associated with amino acid metabolism (e.g., alaine, aspartate, glutamate metabolism), TCA cycle, exosome metabolism, pyrimidine metabolism, purine metabolism, transfer RNA biogenesis, DNA replication proteins, oxidative phosphorylation, and carbon fixation pathways in prokaryotes, and were enriched only in T2 in the tillering stage, while chromosome and associated proteins, secretion system, and bacterial motility proteins were enriched in soil samples from NT (Figure 6b). It can be concluded that chemical fertilizer, indeed, enhanced rhizosphere microbial metabolism, while that of function was inhibited by seaweed-extract-supplement fertilizer.

\subsection{Improvement in Productivity and Quality of Japonica Rice by Seaweed Extract}

As shown in Figure 7, the rice yield of T2, T3, and T4 increased by $58.42 \%, 62.51 \%$, and $62.06 \%$ of that T1 $(p<0.05)$, and those of T3 and T4 slightly increased compared to that of

$\mathrm{T} 2$. There was no significant difference in rice yield among T2, T3, and T4.

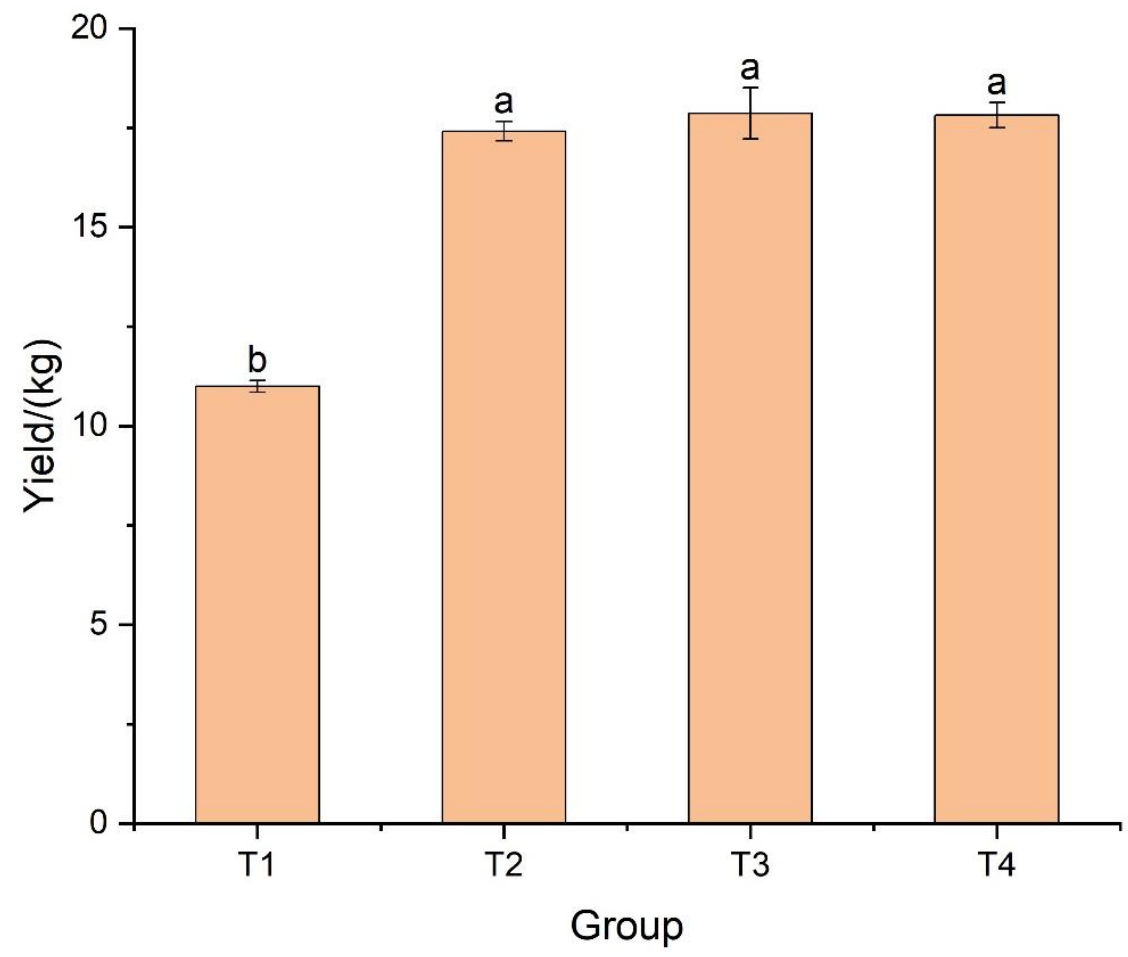

Figure 7. The effect of seaweed extract on rice yield. Means that are followed by the same letter indicate no significant difference $(n=3)$; means with standard error bars are indicated.

Grain quality is evaluated by the appearance and nutritional indexes. The milled rice rate and protein content was greater in $\mathrm{T} 3$ than that in $\mathrm{T} 2$. The chalkiness degree and chalky rice rate decreased in T3 and T4. However, it is strange that T1 had the lowest chalkiness degree and chalkiness rice rate (Table 3), possibly due to the lower speed of starch synthesis.

Table 3. The quality index of japonica rice in different groups.

\begin{tabular}{cccccccc}
\hline Group & $\begin{array}{c}\text { Brown Rice } \\
\text { Rate (\%) }\end{array}$ & $\begin{array}{c}\text { Milled Rice } \\
\text { Rate (\%) }\end{array}$ & $\begin{array}{c}\text { Chalkiness } \\
\text { Degree (\%) }\end{array}$ & $\begin{array}{c}\text { Chalky Rice } \\
\text { Rate (\%) }\end{array}$ & $\begin{array}{c}\text { Protein } \\
\text { Content (\%) }\end{array}$ & $\begin{array}{c}\text { Adhesive } \\
\text { Strength (mm) }\end{array}$ & $\begin{array}{c}\text { Amylose } \\
\text { Content (\%) }\end{array}$ \\
\hline T1 & 84.9 & 76.6 & 1.2 & 8 & 7.12 & 74 & 10.6 \\
T2 & 86.6 & 76.9 & 3.4 & 22 & 7.89 & 79 & 10.3 \\
T3 & 86.1 & 77.4 & 1.8 & 10 & 8.76 & 78 & 10.1 \\
T4 & 85.5 & 75.6 & 2.4 & 13 & 7.54 & 70 & 10.3 \\
\hline
\end{tabular}




\section{Discussion}

\subsection{Rhizosphere Bacteria Dynamics in the Tillering and Heading Stage of Rice}

Root of rice is a hidden organ in soil that mediates critical functions, involving the uptake and storage of nutrients and water [2]. Rhizosphere microbes are critical for plant growth and biogeochemical cycles [46], and are closely related to cultivated crop, fertilizer applications, plant residue input, and other activities [17,31,47,48].

To reveal the change in rhizosphere bacteria of rice spatiotemporally, we studied its variance in sparse time points in different fertilization treatments and growth stages. Actinobacteriota, Protebobacteria, Acidobacteriota, Bacteroidota, Firmicutes, and Chloroflexi were the dominant phyla in rice root in the two growth stages (Figures 2a and 4a). In line with previous studies, roots of monocots and dicots mainly associate with Proteobacteria, Actinobacteria, Bacteroidetes, and Firmicutes [49]. These bacterial communities are related to sulfate reduction, Fe (III) reduction, and methane oxidation to benefit rice growth [32,50]. Actinobacteriota has potential for polyphosphate and glycogen accumulation and nitrate reduction [51], Chloroflexi is positively correlated to soil organic matter for available phosphorus and potassium [52], and Acidobacteriota could reduce nitrate to nitrite and ammonia [33,51,53]. Moreover, Enterobacteriaceae is a large family of Gram-negative, facultative anaerobic bacteria, and most of them are capable of nitrogen fixation [54]. Latescibacterota is positively correlated to total nitrogen, total phosphorus, and total potassium [52].

In the heading stage, Proteobacteria and Bacteroidota in the root could be enriched, while Acidobacteriota decreased. It was reported that fertilization altered the life-history strategy of soil microbes, resulting in an increase in relative abundance of copiotrophic microbes, such as rapid growth of $\beta$-Proteobacteria and Bacteroides and decrease in relative abundance of oligotrophic microbes of Acidobacteria. Zhang et al. reported that indica rice have higher relative abundance of $\delta$-Proteobacteria, while japonica rice has higher relative abundance of $\alpha$-Proteobacteria [33].

The diversity and richness in rhizosphere soil was closely related to soil ecological function, especially when soil biodiversity was lower. A greater bacterial diversity is related to a big change in soil ecological functions of carbon mineralization, nitrogen fixation, denitrification, and organic matter decomposition [3,55]. In this study, the Chao 1 index, Shannon index, and unique OTUs increased in soil samples of the treatment groups, indicating enhancement in bacterial community richness and diversity. This result was in line with previous studies that seaweed extract could increase the number of soil microbial colonies, respiration, nitrogen mobilization, and metabolic activity by improving the bacterial diversity and richness, shifting microbial community structure significantly $[24,56,57]$. Improvement in soil biodiversity would reduce the ability of colonization of pathogens in soil, enhance its environmental adaptation, and decrease the potential interference on soil functions due to the change in microbial richness [58].

Seaweed extract supplement altered the composition and diversity of the rhizosphere bacterial community in different stages (Figures 2 and 4); the bacterial composition was changed in the tillering stage and the bacterial diversity was changed in the heading stage. A study proved that rhizosphere bacteria underwent great changes in various stages; rhizosphere microbes were recruited by the host plants in early growth stages [59], changed dramatically in different vegetative stages, and stabilized from the beginning of the reproductive stage [60].

Rhizosphere bacterial communities represented specific ecologically functional categories by stimulating various metabolism pathways, including cellular process, environmental information process, genetic information process, and nutrient-energy metabolism. These metabolism pathways revealed effects of environmental variance on rhizosphere bacteria [9]. For example, by stimulating the tryptophan biosynthesis pathway that is related to the generation of indole-3-acetice acid in rhizosphere microbiota, plant growth was promoted [2]. Some potentially upregulated pathways, including DNA repair, secretion system, and ribosome biogenesis, could enable the colonization of alien microbes on rice plant [61]. In this study, the supplement of chemical fertilizer with seaweed extract could 
weaken the multiple metabolism pathways and genetic information process in rhizosphere microbiota, suggesting that the seaweed extract supplement has a considerable impact on root microbiota metabolism under fixed environmental conditions; it will be important to identify key pathways involved in rhizosphere microbiota variation in rice. Besides, enhancing enzymatic activity and soil respiration rate of soil is another function of the microbial community $[22,24,61]$, enlightening us to use these indicators for future study.

\subsection{Effect of Seaweed Extract Supply on Nutrient Absorption in Rice Rhizosphere Soil}

Original properties and external inputs could greatly affect soil nutrients. In the present study, all the experimental fields were almost homogenous due to frequent cultivation and ploughing in advance (Table 1). However, the results show that the T3 group had a higher level of N, P, and $\mathrm{K}$ than other groups in the tillering stage (Figure 3). The results are consistent with previous reports that, by seaweed extract treatment, the contents of nitrate nitrogen and ammonium nitrogen of maize root soil were much higher than those of the control [28]. The increase in soil nutrients was reportedly associated with rhizosphere bacteria. For example, it was revealed that Acidobacteriota could reduce nitrate into nitrite and ammonia being favorable to effective use by rice $[33,51,53]$. Therefore, it is possible that, in T3 group, the effectiveness of nitrate reduction to nitrite and ammonia was slowed down by reducing relative abundance of Acidobacteriota to enhance N content (Figure 2a). Spearman analysis provided more information about the relationship between root soil nutrients and bacterial abundance.

Similar results were reported in tomato soil [13], in which seaweed extract increased nitrate nitrogen in the tomato soil significantly. In general, seaweed extract is the source of organic matter and nutrients, so the utilization of seaweed extract as biofertilizer could compensate the deficiency of N, P, and K in soils [62]. In addition, it can also be decomposed for later releases of nitrate, ammonium, total nitrogen, and phosphorus [63]. Moreover, as occurred in $S$. horneri extract, alginate can chelate with major cations of $\mathrm{Na}^{+}, \mathrm{Ca}^{2+}, \mathrm{Mg}^{2+}$, and $\mathrm{K}^{+}$to form aggregate with richer nutrients [21], improve the crumb structure and capillary activity of soil pores, and, finally, boost soil microbial activity [64]. Therefore, seaweed extract supplement can potentially be a strategy of enhancing the level of N, P, and $\mathrm{K}$ contents in soil.

\subsection{Effects of Seaweed Extract Supply on Rice Yield and Quality}

Seaweed extract supplement to fertilizer increased the rice yield slightly and, especially, the amount of fertilizer applied was saved by $20 \%$ in the rice experiment (T4) (Figure 2). These results agree with findings of previous studies: seaweed extract improved productivity of tomato [13], cucumber [23], hot pepper [15], strawberry [56], and maize [28,29], and promoted plant heading [18], benefitted growth of crop roots and seedlings [24], enhanced soil nutrient absorption, and increased microbial activity [65]. In fact, the rises in N, P, and $\mathrm{K}$ contents play outstanding physiological roles of increasing the grain size, kernel weight, and the yield, and promoting tillering [66]. In this study, seaweed extract supplement decreased chalkiness degree and rate, and improved protein content (Table 3). Rice chalkiness is caused by loosely arranged starch granules [67]; it is a property of the opaque part of the endosperm, which affects rice appearance, milling rate, and taste [68,69]. In many studies, chalkiness is focused on the starch synthesis [67], and it could possibly explain why T1 had the lowest chalkiness degree and rate due to lower speed of starch synthesis caused by nutrient deficiency.

Alginate oligosaccharides in S. horneri extract are another potential factor that needs to be considered. Alginate oligosaccharides could promote plant rooting, such as the length, tips, volume, and fresh weight of root, as shown in a study of Brassica campestris L. [70]. Alginate oligosaccharides could stimulate the heading of barley roots [57], improve the fresh weight of tobacco, enhance the level of glutathione and ascorbic acid of tobacco leaf [71], and increase the active ingredients in medicinal plants [72]. Furthermore, it is proved that a small amount of alginate oligosaccharides could be enough to act on plants in different 
ways. By application of alginate oligosaccharides $(10-80 \mathrm{mg} / \mathrm{L})$, the expression of auxinrelated gene in rice (Oryza sativa L.) was induced and calcium signaling was generated, which accelerated the auxin biosynthesis and transport and reduced indole-3-acetic acid oxidase activity, and, finally, promoted root growth and the rice yield [73]. Alginate oligosaccharides could also stimulate the generation of nitric oxide and regulate nitrogen metabolism by activating related enzyme activities [58,74], and benefit the rhizosphere microbiota for better growth performance. In the future, more studies shall be carried out on alginate oligosaccharides in depth [73,74].

Moving forward, the results in the literature, as well as those provided by the current study, provide evidence for the use and exploitation of seaweed extracts to obtain sustainable advantages in agricultural application. In addition, it would be interesting to carry out a long-term experiment and to see if the yield of succeeding crops shows an increased level of rhizosphere microorganisms.

\section{Conclusions}

Having studied the effects of seaweed extract supplement on rhizosphere bacteria for japonica rice in two key growth stages of tillering and heading, we find that the composition of the rhizosphere bacterial community was modified and bacterial diversity and richness of rice increased. Moreover, soil nutrient level in the tillering stage was enhanced, and quality and yield improved. Adding a small amount of seaweed extract into chemical fertilizer was shown to be a potential strategy to improve soil nutrient levels, rhizosphere bacterial diversity and richness, and increased rice yield and quality. The cost of chemical fertilizer could be saved by about $20 \%$.

More studies shall be performed in the future in different designs in dosage of seaweed extract supplement for longer application times with more growth indexes under different conditions (different climate condition, different soil properties, and various plants, etc.) to explore, overall, the potential mechanism of seaweed extract supplement action for better understanding and strategy of seaweed extract supplement in chemical fertilizer. Besides, bioactive compounds of the seaweed extract potentially make a difference in plant growth and rhizosphere community, and further study for profiles of bioactive components is also valuable.

Author Contributions: Conceptualization, Z.-Y.L., W.-L.S. and D.-W.F.; methodology, Z.-Y.L., C.-L.C., L.S., Z.-H.Z. and Q.-Q.L.; investigation, C.-L.C., W.-L.S., L.S. and N.L.; formal analysis, C.-L.C.; resources, J.-C.Y., J.Y. and B.-B.C.; writing-original draft preparation, C.-L.C. and Z.-D.L.; writingreview and editing, C.-L.C., C.-G.R., Z.-Y.L. and D.-W.F.; visualization, C.-L.C.; supervision, S.Q. and Z.-Y.L.; project administration, Z.-Y.L.; funding acquisition, Z.-Y.L. and S.Q. All authors have read and agreed to the published version of the manuscript.

Funding: This research was funded by the Key Research and Development Program of Yantai (Nos. 2020MSGY068, 2019MSGY123, 2020XCZX024), Development Plan of Shandong Province (No. 2019GSF109104) and Shandong Natural Science Foundation (ZR2021MC106). The APC was funded by the Key Research and Development Program of Yantai (No. 2020MSGY068).

Data Availability Statement: The datasets generated for this study are available upon request from the corresponding author.

Acknowledgments: We thank Yong-Dong $\mathrm{Xu}$ for his support in the original draft preparation for the manuscript.

Conflicts of Interest: The authors declare no conflict of interest.

\section{References}

1. Sasse, J.; Martinoia, E.; Northen, T. Feed your friends: Do plant exudates shape the root microbiome? Trends Plant Sci. 2018, 23, 25-41. [CrossRef] [PubMed]

2. Pascale, A.; Proietti, S.; Pantelides, I.S.; Stringlis, I.A. Modulation of the root microbiome by plant molecules: The basis for targeted disease suppression and plant growth promotion. Front. Plant Sci. 2019, 10, 1741. [CrossRef] [PubMed] 
3. Feng, Y.; Chen, R.; Hu, J.; Zhao, F.; Wang, J.; Chu, H.; Zhang, J.; Dolfing, J.; Lin, X. Bacillus asahii comes to the fore in organic manure fertilized alkaline soils. Soil Biol. Biochem. 2015, 81, 186-194. [CrossRef]

4. Habibi, S.; Djedidi, S.; Prongjunthuek, K.; Mortuza, M.F.; Ohkama-Ohtsu, N.; Sekimoto, H.; Yokoyoma, T. Physiological and genetic characterization of rice nitrogen fixer PGPR isolated from rhizosphere soils of different crops. Plant. Soil 2014, $379,51-66$. [CrossRef]

5. Maeder, P.; Fliessbach, A.; Dubois, D.; Gunst, L.; Fried, P.; Niggli, U. Soil fertility and biodiversity in organic farming. Science 2002, 296, 1694-1697. [CrossRef]

6. Molina-Santiago, C.; Matilla, M.A. Chemical fertilization: A short-term solution for plant productivity? Microb. Biotechnol. 2020, 13, 1311-1313. [CrossRef]

7. Berg, G.; Smalla, K. Plant species and soil type cooperatively shape the structure and function of microbial communities in the rhizosphere. FEMS Microbiol. Ecol. 2009, 68, 1-13. [CrossRef]

8. Huang, R.; McGrath, S.P.; Hirsch, P.R.; Clark, I.M.; Storkey, J.; Wu, L.; Zhou, J.; Liang, Y. Plant-microbe networks in soil are weakened by century-long use of inorganic fertilizers. Microb. Biotechnol. 2019, 12, 1464-1475. [CrossRef]

9. Zhang, Q.-C.; Shamsi, I.H.; Xu, D.-T.; Wang, G.-H.; Lin, X.-Y.; Jilani, G.; Hussain, N.; Chaudhry, A.N. Chemical fertilizer and organic manure inputs in soil exhibit a vice versa pattern of microbial community structure. Appl. Soil Ecol. 2012, 57, 1-8. [CrossRef]

10. Wang, B.; Gao, B.; Zimmerman, A.R.; Zheng, Y.; Lyu, H. Novel biochar-impregnated calcium alginate beads with improved water holding and nutrient retention properties. J. Environ. Manag. 2018, 209, 105-111. [CrossRef]

11. Wei, M.; Hu, G.; Wang, H.; Bai, E.; Lou, Y.; Zhang, A.; Zhuge, Y. 35 years of manure and chemical fertilizer application alters soil microbial community composition in a Fluvo-aquic soil in Northern China. Eur. J. Soil Biol. 2017, 82, 27-34. [CrossRef]

12. Ning, C.-C.; Gao, P.-D.; Wang, B.-Q.; Lin, W.-P.; Jiang, N.-H.; Cai, K.-Z. Impacts of chemical fertilizer reduction and organic amendments supplementation on soil nutrient, enzyme activity and heavy metal content. J. Integr. Agric. 2017, 16, 1819-1831. [CrossRef]

13. Hussain, H.I.; Kasinadhuni, N.; Arioli, T. The effect of seaweed extract on tomato plant growth, productivity and soil. J. Appl. Phycol. 2021, 33, 1305-1314. [CrossRef]

14. Peng, C.; Lai, S.; Luo, X.; Lu, J.; Huang, Q.; Chen, W. Effects of long term rice straw application on the microbial communities of rapeseed rhizosphere in a paddy-upland rotation system. Sci. Total Environ. 2016, 557-558, 231-239. [CrossRef] [PubMed]

15. Ashour, M.; Hassan, S.M.; Elshobary, M.E.; Ammar, G.A.G.; Gaber, A.; Alsanie, W.F.; Mansour, A.T.; El-Shenody, R. Impact of Commercial Seaweed Liquid Extract (TAM $®)$ Biostimulant and its bioactive molecules on growth and antioxidant activities of hot pepper (Capsicum annuum). Plants 2021, 10, 1045. [CrossRef] [PubMed]

16. Gupta, S.; Stirk, W.A.; Plackova, L.; Kulkarni, M.G.; Dolezal, K.; Van Staden, J. Interactive effects of plant growth-promoting rhizobacteria and a seaweed extract on the growth and physiology of Allium cepa L. (onion). J. Plant Physiol. 2021, $262,153437$. [CrossRef] [PubMed]

17. Thiele-Bruhn, S.; Bloem, J.; de Vries, F.T.; Kalbitz, K.; Wagg, C. Linking soil biodiversity and agricultural soil management. Curr. Opin. Environ. Sustain. 2012, 4, 523-528. [CrossRef]

18. Battacharyya, D.; Babgohari, M.Z.; Rathor, P.; Prithiviraj, B. Seaweed extracts as biostimulants in horticulture. Sci. HorticAmestersam 2015, 196, 39-48. [CrossRef]

19. Colla, G.; Cardarelli, M.; Bonini, P.; Rouphael, Y. Foliar applications of protein hydrolysate, plant and seaweed extracts increase yield but differentially modulate fruit quality of greenhouse tomato. HortScience 2017, 52, 1214-1220. [CrossRef]

20. De Saeger, J.; Van Praet, S.; Vereecke, D.; Park, J.; Jacques, S.; Han, T.; Depuydt, S. Toward the molecular understanding of the action mechanism of Ascophyllum nodosum extracts on plants. J. Appl. Phycol. 2020, 32, 573-597. [CrossRef]

21. Khan, W.; Rayirath, U.P.; Subramanian, S.; Jithesh, M.N.; Rayorath, P.; Hodges, D.M.; Critchley, A.T.; Craigie, J.S.; Norrie, J.; Prithiviraj, B. Seaweed extracts as biostimulants of plant growth and development. J. Plant Growth Regul. 2009, 28, 386-399. [CrossRef]

22. Tejada, M.; Benítez, C.; Gómez, I.; Parrado, J. Use of biostimulants on soil restoration: Effects on soil biochemical properties and microbial community. Appl. Soil Ecol. 2011, 49, 11-17. [CrossRef]

23. Hassan, S.M.; Ashour, M.; Sakai, N.; Zhang, L.; Hassanien, H.A.; Gaber, A.; Ammar, G. Impact of seaweed liquid extract biostimulant on growth, yield, and chemical composition of cucumber (Cucumis sativus). Agriculture 2021, 11, 320. [CrossRef]

24. Wang, M.; Chen, L.; Li, Y.; Chen, L.; Liu, Z.; Wang, X.; Yan, P.; Qin, S. Responses of soil microbial communities to a short-term application of seaweed fertilizer revealed by deep amplicon sequencing. Appl. Soil Ecol. 2018, 125, 288-296. [CrossRef]

25. Mukherjee, A.; Patel, J.S. Seaweed extract: Biostimulator of plant defense and plant productivity. Int. J. Environ. Sci. Technol. 2020, 17, 553-558. [CrossRef]

26. Al-Taweel, L.S.; Al-Budairy, Z.J. Influence of Vermicompost, Seaweed Extract and Nitrogen Fertilisers on Maize (Zea mays L.) Soil Rhizosphere Microbes. Asian J. Water Environ. 2021, 18, 79-85. [CrossRef]

27. Tawfeeq, A.; Culham, A.; Davis, F.; Reeves, M. Does fertilizer type and method of application cause significant differences in essential oil yield and composition in rosemary (Rosmarinus officinalis L.)? Ind. Crop. Prod. 2016, 88, 17-22. [CrossRef]

28. Chen, Y.; Li, J.; Huang, Z.; Su, G.; Li, X.; Sun, Z.; Qin, Y. Impact of short-term application of seaweed fertilizer on bacterial diversity and community structure, soil nitrogen contents, and plant growth in maize rhizosphere soil. Folia Microbiol. 2020, 65, 591-603. [CrossRef] 
29. Arioli, T.; Mattner, S.W.; Hepworth, G.; McClintock, D.; McClinock, R. Effect of seaweed extract application on wine grape yield in Australia. J. Appl. Phycol. 2021, 33, 1883-1891. [CrossRef]

30. Shen, Y.; Wang, H.; Li, W.; Liu, Z.; Liu, Y.; Wei, H.; Li, J. Synthesis and characterization of double-network hydrogels based on sodium alginate and halloysite for slow release fertilizers. Int. J. Biol. Macromol. 2020, 164, 557-565. [CrossRef]

31. Edwards, J.; Johnson, C.; Santos-Medellin, C.; Lurie, E.; Podishetty, N.K.; Bhatnagar, S.; Eisen, J.A.; Sundaresan, V. Structure, variation, and assembly of the root-associated microbiomes of rice. Proc. Natl. Acad. Sci. USA 2015, 112, E911-E920. [CrossRef]

32. Sun, W.; Xiao, E.; Pu, Z.; Krumins, V.; Dong, Y.; Li, B.; Hu, M. Paddy soil microbial communities driven by environment- and microbe-microbe interactions: A case study of elevation-resolved microbial communities in a rice terrace. Sci. Total Environ. 2018, 612, 884-893. [CrossRef]

33. Zhang, J.; Liu, Y.X.; Zhang, N.; Hu, B.; Jin, T.; Xu, H.; Qin, Y.; Yan, P.; Zhang, X.; Guo, X. NRT1.1B is associated with root microbiota composition and nitrogen use in field-grown rice. Nat. Biotechnol. 2019, 37, 676-684. [CrossRef]

34. Vafa, Z.N.; Sohrabi, Y.; Sayyed, R.Z.; Luh Suriani, N.; Datta, R. Effects of the combinations of rhizobacteria, mycorrhizae, and seaweed, and supplementary irrigation on growth and yield in wheat cultivars. Plants 2021, 10, 811. [CrossRef]

35. Hasnain, M.; Chen, J.; Ahmed, N.; Memon, S.; Wang, L.; Wang, Y.; Wang, P. The Effects of fertilizer type and application time on soil properties, plant traits, yield and quality of tomato. Sustainability 2020, 12, 9065. [CrossRef]

36. Hernández, T.; Chocano, C.; Moreno, J.-L.; García, C. Towards a more sustainable fertilization: Combined use of compost and inorganic fertilization for tomato cultivation. Agric. Ecosyst. Environ. 2014, 196, 178-184. [CrossRef]

37. Norman, R.J.; Edberg, J.C.; Stucki, J.W. Determination of nitrate in soil extracts by dual-wavelength ultraviolet spectrophotometry. Soil Sci. Soc. Am. J. 1985, 49, 1182-1185. [CrossRef]

38. Bray, R.H.; Kurtz, L.T. Determination of total, organic and available forms of phosphorus in soils. Soil Sci. 1945, 59, 39-45. [CrossRef]

39. Carson, P.L. Recommended potassium test. North Dak. Agric. Exp. Stn. Bull. 1980, 17-18.

40. Wang, M.; Chen, L.; Liu, Z.; Zhang, Z.; Qin, S.; Yan, P. Isolation of a novel alginate lyase-producing Bacillus litoralis strain and its potential to ferment Sargassum horneri for biofertilizer. Microbiologyopen 2016, 5, 1038-1049. [CrossRef]

41. Caporaso, J.G.; Kuczynski, J.; Stombaugh, J.; Bittinger, K.; Bushman, F.D.; Costello, E.K.; Fierer, N.; Peña, A.G.; Goodrich, J.K.; Gordon, J.I. QIIME allows analysis of high-throughput community sequencing data. Nat. Methods 2010, 7, 335-336. [CrossRef]

42. Rognes, T.; Flouri, T.; Nichols, B.; Quince, C.; Mahe, F. VSEARCH: A versatile open source tool for metagenomics. PeerJ 2016, 4, e2584. [CrossRef]

43. Quast, C.; Pruesse, E.; Yilmaz, P.; Gerken, J.; Schweer, T.; Yarza, P.; Peplies, J.; Glockner, F.O. The SILVA ribosomal RNA gene database project: Improved data processing and web-based tools. Nucleic Acids Res. 2013, 41, D590-D596. [CrossRef]

44. Edgar, R.C. UPARSE: Highly accurate OTU sequences from microbial amplicon reads. Nat. Methods 2013, 10, 996-998. [CrossRef]

45. Wang, Q.; Garrity, G.M.; Tiedje, J.M.; Cole, J.R. Naive Bayesian classifier for rapid assignment of rRNA sequences into the new bacterial taxonomy. Appl. Environ. Microbiol. 2007, 73, 5261-5267. [CrossRef]

46. Li, H.; Su, J.Q.; Yang, X.R.; Zhu, Y.G. Distinct rhizosphere effect on active and total bacterial communities in paddy soils. Sci. Total Environ. 2019, 649, 422-430. [CrossRef]

47. Frindte, K.; Zoche, S.A.; Knief, C. Development of a distinct microbial community upon first season crop change in soils of long-term managed maize and rice fields. Front. Microbiol. 2020, 11, 588198. [CrossRef]

48. Zhou, X.; Wang, J.T.; Zhang, Z.F.; Li, W.; Chen, W.; Cai, L. Microbiota in the rhizosphere and seed of rice from China, With Reference to Their Transmission and Biogeography. Front. Microbiol. 2020, 11, 995. [CrossRef]

49. Muller, D.B.; Vogel, C.; Bai, Y.; Vorholt, J.A. The plant microbiota: Systems-level insights and perspectives. Annu. Rev. Genet. 2016, 50, 211-234. [CrossRef]

50. Doi, T.; Abe, J.; Shiotsu, F.; Morita, S. Study on rhizosphere bacterial community in lowland rice grown with organic fertilizers by using PCR-denaturing gradient gel electrophoresis. Plant. Root 2011, 5, 5-16. [CrossRef]

51. Kristensen, J.M.; Singleton, C.; Clegg, L.A.; Petriglieri, F.; Nielsen, P.H. High diversity and functional potential of undescribed "Acidobacteriota" in Danish wastewater treatment plants. Front. Microbiol. 2021, 12, 643950. [CrossRef]

52. Wu, T.; Qin, Y.; Li, M. Intercropping of tea (Camellia sinensis L.) and Chinese chestnut: Variation in the structure of rhizosphere bacterial communities. J. Soil Sci. Plant Nutr. 2021, 21, 2178-2190. [CrossRef]

53. Bloom, A.J. The increasing importance of distinguishing among plant nitrogen sources. Curr. Opin. Plant Biol. 2015, 25, 10-16. [CrossRef]

54. Mehnaz, S. Microbes-Friends and foes of sugarcane. J. Basic Microbiol. 2013, 53, 954-971. [CrossRef]

55. Bender, S.F.; Wagg, C.; van der Heijden, M.G.A. An underground revolution: Biodiversity and soil ecological engineering for agricultural sustainability. Trends Ecol. Evol. 2016, 31, 440-452. [CrossRef]

56. Alam, M.Z.; Braun, G.; Norrie, J.; Mark Hodges, D. Ascophyllum extract application can promote plant growth and root yield in carrot associated with increased root-zone soil microbial activity. Can. J. Plant Sci. 2014, 94, 337-348. [CrossRef]

57. Natsume, M.; Kamo, Y.; Hirayama, M.; Adachi, T. Isolation and characterization of alginate-derived oligosaccharides with root growth-promoting activities. Carbohydr. Res. 1994, 258, 187-197. [CrossRef]

58. Nielsen, U.N.; Ayres, E.; Wall, D.H.; Bardgett, R.D. Soil biodiversity and carbon cycling: A review and synthesis of studies examining diversity-function relationships. Eur. J. Soil. Sci. 2011, 62, 105-116. [CrossRef] 
59. Feng, J.; Franks, A.E.; Lu, Z.; Xu, J.; He, Y. Assembly and variation of root-associated microbiota of rice during their vegetative growth phase with and without lindane pollutant. SEL 2020, 3, 207-219. [CrossRef]

60. Zhang, J.; Zhang, N.; Liu, Y.X.; Zhang, X.; Hu, B.; Qin, Y.; Xu, H.; Wang, H.; Guo, X.; Qian, J. Root microbiota shift in rice correlates with resident time in the field and developmental stage. Sci. China Life Sci. 2018, 61, 613-621. [CrossRef]

61. Jacobs, J.L.; Sundin, G.W. Effect of solar UV-B radiation on a phyllosphere bacterial community. Appl. Environ. Microbiol. 2001, 67, 5488-5496. [CrossRef]

62. Nabti, E.; Jha, B.; Hartmann, A. Impact of seaweeds on agricultural crop production as biofertilizer. Int. J. Environ. Sci. Technol. 2016, 14, 1119-1134. [CrossRef]

63. Nedzarek, A. Decomposition of macroalgae and the release of nutrient in Admiralty Bay, King George Island, Antarctica. Polar Biosci. 2004, 17, 26-35.

64. Yang, S.H.; Seo, J.; Koo, Y. Alginate and fucoidan changes the bacterial community in different directions and the alginate or fucoidan degrading bacteria isolated from paddy soil promotes the plant growth. Arch. Microbiol. 2021, 203, 5183-5192. [CrossRef]

65. Kumar, D.; Singh, A.P. Efficacy of potassium humate and chemical fertilizers on yield and nutrient availability patterns in soil at different growth stages of rice. Commun. Soil Sci. Plan. 2017, 48, 245-261. [CrossRef]

66. Yang, L.; Elisa, N.; Eliot, N. Privacy and security aspects of E-Government in smart cities. In Smart Cities Cybersecurity and Privacy; Elsevier: Amsterdam, The Netherlands, 2019; pp. 89-102.

67. Wang, C.-X.; Zhu, C.-C.; Lu, C.-Y.; Yang, Y.; Li, Q.-F.; Liu, Q.-Q.; Zhang, C.-Q. Grain quality and starch physicochemical properties of chalky rice mutant. Agronomy 2021, 11, 1575. [CrossRef]

68. Cheng, F.M.; Zhong, L.J.; Wang, F.; Zhang, G.P. Differences in cooking and eating properties between chalky and translucent parts in rice grains. Food Chem. 2005, 90, 39-46. [CrossRef]

69. Zhu, A.; Zhang, Y.; Zhang, Z.; Wang, B.; Xue, P.; Cao, Y.; Chen, Y.; Li, Z.; Liu, Q.; Cheng, S. Genetic dissection of qPCG1 for a quantitative trait locus for percentage of chalky grain in rice (Oryza sativa L.). Front. Plant. Sci. 2018, 9, 1173. [CrossRef]

70. Yun-hong, Z.; Li-shu, W.U.; Ming-jian, G.; Hong-qing, H.U.; Shan-xue, Z. Effects of Several Oligosaccharides on the Yield and Quality of Brassica chinensis. J. Huazhong Agric. Univ. 2009, 28, 164-168.

71. Laporte, D.; Vera, J.; Chandía, N.P.; Zúñiga, E.A.; Matsuhiro, B.; Moenne, A. Structurally unrelated algal oligosaccharides differentially stimulate growth and defense against tobacco mosaic virus in tobacco plants. J. Appl. Phycol. 2006, 19, 79-88. [CrossRef]

72. Zhang, C.; Wang, W.; Zhao, X.; Wang, H.; Yin, H. Preparation of alginate oligosaccharides and their biological activities in plants: A review. Carbohydr. Res. 2020, 494, 108056. [CrossRef]

73. Zhang, Y.; Yin, H.; Zhao, X.; Wang, W.; Du, Y.; He, A.; Sun, K. The promoting effects of alginate oligosaccharides on root development in Oryza sativa L. mediated by auxin signaling. Carbohydr. Polym. 2014, 113, 446-454. [CrossRef]

74. Zhang, Y.H.; Yin, H.; Liu, H.; Wang, W.X.; Wu, L.S.; Zhao, X.M.; Du, Y.G. Alginate oligosaccharides regulate nitrogen metabolism via calcium in Brassica campestris L. var. utilis Tsen et Lee. J. Hortic. Sci. Biotechnol. 2015, 88, 502-508. [CrossRef] 